\title{
BACK PAY AWARDS FOR UNFAIR LABOR PRACTICES UNDER THE TAFT-HARTLEY ACT
}

WORKERS frequently suffer involuntary pay loss when employers or unions engage in practices proscribed by the National Labor Relations Act. ${ }^{1}$ limployers, ${ }^{2}$ for example, may interfere with the right of their employees to engage in concerted activities: ${ }^{3}$ may discharge or otherwise discriminate against workers who testify or bring charges under the Act $; 4$ or may discriminate in regard to hire or tenure of employment for the purpose of encouraging or discouraging union membership. ${ }^{5}$ Unions, ${ }^{6}$ on the other hand, may cause

1. 49 Stat. 449 (1935), 29 U.S.C. \& 151 (1946), as amended by the Labor-Maunagement Relations Act of 1947, 61 StAт. 136 (1947), 29 U.S.C. $\$ \$ 141$ at seq. (Supp. 1952) (hereinafter referred to as Taft-Hartley Act).

For a general discussion of the Act before its amendment, see Mutus \& Brown, Fitom The Wagner Act to Taft-Hartiey cc. $1-7$ (1950); Siluerberg, The Wagnek Act: AfTER TeN YeArs (1945). For legislative history of the amendment, see NLRB, LEGISlative History of the Labor Management Relations Act (1948).

2. For a discussion of employer unfair labor practices, sec Millas \& Brows, op. cil. supra note 1, at cc. 4, 5, 6, 12; IVERne, The LAW of LABOR ReLATIONs 189-299 (1951); Wollett, Labor Relations aNi) Federal. LAw 56-85 (1949).

3. Section 8(a) (1):

"It shall be an unfair practice for an employer-(1) to interfere with, restrain, or coerce employees in the exercise of the rights guaranteed in Section 7." 61 STAT. 140 (1947), 29 U.S.C. $\$ 158$ (a) (1) (Supp. 1952).

Section 7 guarantees to employees the right to organize, to bargain collectively through representatives of their own choosing, and to engage in concerted activities for their mutual aid or protection. To these rights, the Taft-Hartley Act adds the "right to rofrain from . . such activities." 61 Stat. 140 (1947), 29 U.S.C. $\$ 157$ (Supp. 1952).

For a discussion of these sections, see WERNE, op. cit. supra note 2, at 189-203. For illustrative cases, see Gullett Gin Co., 83 N.L.R.B. 1 (1949); Phoenix Mutual Life Ins. Co., 73 N.L.R.B. 1463 (1947), enforcement granted, 167 F.2d 983 (7th Cir. 1948), 49 CoL. L. REv. 277 (1949), 24 Iro. L.J. 273 (1949) (pre-Taft-Hartley decision).

4. Section 8(a) (4):

"It shall be an unfair labor practice for an employer-(4) to discharge or otherwise discriminate against an employce because he has filed charges or given testimony under this Act." 61 StaT. 141 (1947), 29 U.S.C. § 158(a) (4) (Supp. 1952).

For a discussion of this section, see WerNe, op. cit. supra note 2 , at 69,136 . For illustrative cases, see South Jersey Coach Lines, 92 N.L.R.B. 791 (1950) (employce discharged for giving testimony); John H. Maclin Peanut Co:, 84 N.L.R.B. 384 (1949) (employee refused reinstatement for having filed charges).

5. Section 8(a) (3) :

"It shall be an unfair labor practice for an employer-(3) by discrimination in regard to hire or tenure of employment or any term or condition of employment to encourage or discourage membership in any labor organization. ..." 61 SrAT. 140 (1947), 29 U.S.C. \$158(a) (3) (Supp. 1952).

For a discussion of this section, see Werse, op. cit. supra nute 2, at 215-23. For an illustrative case, see Thomas W. Dant, 92 N.L.R.B. 307 (1950).

6. For a general discussion of the background and scope of the union unfair labor practices, see Mlillis \& Brown, op. cit. supra note 1, at cc. 8, 9, 10, 12; Wollets, 
an employer to discriminate in order to encourage union membership, or may forcibly keep employees from their jobs. ${ }^{8}$ Other types of employer and union conduct are also illegal under the Act ; but they do not commonly lead to loss of pay. ${ }^{9}$

op. cit. supra note 2, at 85-95: Cos, Sime .Aspits of the Lathor-Mananiment Kolations Act, 1947, 61 HARv. L. REv. 1, 24-34 (1947): Foles, ('nim" l'nfiair Iathar Practices Under the Taft-Hartley Act. 33 V.. L. Rev. 697 (1947): Somers, The Nationd Labor Relations Board from Waumer to Tuft-Harlley: A Study in Transilinn aud Adophation. 9 FED. B.J. 315, 317-19 (194S).

7. Section $S(b)(2)$ :

"It shall be an unfair labor practice for a labor organization or its agents-(2) to cause or attempt to cause an employer to discriminate against an employee in violation of subsection (a) (3) [see note 5 stpra] or to discriminate against an employee with respect to whom membership in such organization has been denied or terminated on $s$ me ground other than his failure to tender the periodic dues and the initiation fees uniformly required as a condition of acquiring or retaining membership." 61 STAт. 141 (1947). 29 U.S.C. $\$ 158(b)(2)$ (Supp. 1952).

For a discussion of this section, see MrLers \& Brows, op. ril. supra nute 1, at 433-f0: WERNE, op. cit. stipra note 2, at 215-23, 232-3; Walsh, Scction Sth)(2) Discrimisation, 2 LAB. L.J. 495 (1951).

For illustrative cases. see Lnion Starch \& Refining Cu. \&7 X.L.R.E. 709 (1949); National Maritime Union of America, 78 N.L.R.B. 971 (1948).

8. Section $8(\mathrm{~b})(1)(\mathrm{A})$ :

"It shall be an unfair labor practice for a labor arganization or its agents-(1) to restrain or coerce (A) employees in the exercise of the rights guaranteed in section 7. ..." 61 Stat. 141 (1947), 29 U.S.C. \$158(b) (1) (A) (Supp. 1952).

Section 7 guarantees employees the right to engage in concerted activities direeted toward self-organization or collective bargaining and also the right to refrain from such activities except under a lawful union shop.

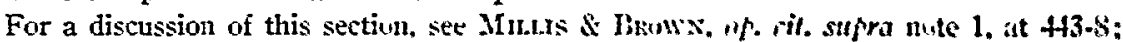

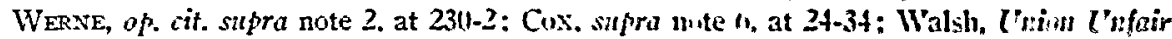
Labor Practices, 1 L.18 L.J. 1095. 1096-8 (1951): Nerilofments in the Lsac-The TaftHartley Act, 64 HARr. L. Rer. 781. 795-8 (1951). Fur illustrative eaces, see United Mine Workers of America. 92 N.L.R.B. 911 (1950) (cuerciun during an organizati -nal campaign) : Local No. 1150, U.E.. Radio \& Machine Whrkers of Ameries, it N.L.R.B. 972 (1949) (violence and threats during a strike).

9. Such employer unfair practices involve domination or interference with the formation or administration of any labor organization or contribution of financial and other support; and refusal to bargain collectively with emiloye representatives. 61 Sr.1T. 140-1 (1947), 29 U.S.C. $\$ \$ 158$ (a) (2) and (5) (Supp. 1952).

Such union unfair practices involve restraining or coercing an "emplayer in the selcetion of his representative for the purposes of collective bargaining or the adjustment of grievances" (\$\$(b) (1)(B)): refusing to bargain cullectively with an empluyer $1 \$ 3($ b) (3)) ; engaging in or inducing a secondary boycott $(\$ \$(b)(4)(A))$; engaging in or inducing the employees of an employer to engage in concerted activities aimed at forcing any other employer to bargain with an uncertified union (\$\$(b)(4)(B)); engaging in or inducing the employees of any employer to engage in concerted activities aimed at forcing an employer to bargain with a particular labor organization as the representative of his employees if another labor organization has already been certified as the representative $(\$ \&(b)$ (4) (C)) ; engaging in "jurisdictional disputes" (\$ \$(b) (4) (D)); exacting excessive or 
To compensate for wage losses incurred by unfair labor practices, the $\mathrm{Na}$ tional Labor Relations Board is empowered to award back pay to the injured workers. ${ }^{10}$ Prior to the Taft-Hartley amendments of 1947, only an employer could be guilty of an unfair labor practice. And the NLRB was given broad power under Section 10 (c), ${ }^{11}$ upon finding "any such unfair labor practice," to issue a cease and desist order and to "take such affirmative action, including reinstatement of employees with or without back pay, as will effectuate the policies of the Act." This section was interpreted broadly enough to justify back pay awards for virtually any unfair practice. ${ }^{12}$ With the passage of Taft-Hartley, however, certain union practices were also made unfair. And Congress added a new proviso to the existing general power: "Provided, that where an order directs reinstatement of an employee, back pay may be required of the employer or labor organization, as the case may be, responsible for the discrimination. . ..."13

Both the NLRB and the Seventh Circuit have read the proviso as a limitation upon the Board's power to grant back pay. They would permit such an

discriminatory admission fees $(\S \&(\mathrm{~b})(5))$; and collecting sums for services not performed (\$ 8(b) (6)). 61 STAT. 141-2 (1947), 29 U.S.C. $\$ 158$ (b) (Supp. 1952).

It is possible, however, that $\S 8(\mathrm{~b})(4)$ violations, standing alone, could lead to pay loss. This might occur, for example, if an employer were forced to shut down by a jurisdictional dispute or secondary boycott.

10. For a discussion of the NLRB's method of computing back pay, see F. W. Woolworth Co., 90 N.L.R.B. 289, 291 (1950). See also Note, 48 YALE L.J. 1265 (1939).

11. 49 Stat. 454 (1935), 29 U.S.C. $\$ 160$ (c) (1946).

12. See Phelps Dodge Corp. v. NLRB, 313 U.S. 177, 188-9 (1941).

13. 61 StaT. 147 (1947), 29 U.S.C. $\$ 160$ (c) (Supp. 1952).

Congress also provided for recovery of losses caused by certain unfair labor practices by means independent of the NLRB. Section 303(a) of the Act proseribes the same activities as do $\S \S 8(\mathrm{~b})(4)(A)-(D)$. Section $303(\mathrm{~b})$ then reads:

"Whoever shall be injured in his business or property by reason of any violation of subsection (a) may sue therefor in a district court of the United States subject to the limitations and provisions of section 301 hereof without respect to the amount in controversy, or in any other court having jurisdiction of the parties, and shall recover the damages by him sustained and the cost of the suit." 61 STAT. 158 (1947), 29 U.S.C. \&187 (Supp. 1952).

Of the 13 reported cases in which damages have been sought under $\$ 303$, only onte case was brought by employees. This case, Schatte v. International Alliance, $182 \mathrm{~F} .2 \mathrm{~d}$ 158 (9th Cir. 1950), cert. denied, 340 U.S. 827 (1951), resulted in a verdict for the defendant. The court found no action violative of $\$ 303(\mathrm{a})$.

For a discussion of the interrelation between $\S 8(\mathrm{~b})(4)$ and $\S 303(\mathrm{~b})$, see Note, 61 YALE L.J. 745 (1952). For material on the various subsections of $\$ 8(b)(4)$, see Mildrs \& Brown, op. cit. supra note 1, at 455-81; WERNE, op. cit. supra note 2, at 237-42; WoLIETT, op. cit. supra note 2, at 88-98; Johns, Picketing and Secondary Boycolts Under the Taft-Hartley Act, 2 LAB. L.J. 257 (1951); Perkins, Basic Labor Lanv Isstles Under the Taft-Hartley Act, 27 B.U.L. Rev. 370, 388-93 (1947); Developments in the LazuThe Taft-Hartley Act, 64 HAnv. L. Rev. 781, 794-810 (1951); Note, Jurisdictional Disputes Under the Taft-Hartley Act, 1 LAB. L.J. 499 (1950). 
award only against a party responsible for "discrimination."14 .11though the Act does not define discrimination, several sections- $S(a)(3), S(3)(4)$ and $S(b)(2)^{15}$-specifically employ the term. But the NI,RB has not confined its back pay awards to violations of these sections. Rather, the requisite discrimination seems to rest upon a finding that there has been a termination of, or interference with, the employment relationship. ${ }^{10}$ Thus, an employer has been held for back pay for a violation of Section $8(a)(1)$-on the ground of discrimination ${ }^{17}$ - even though the section itself does not mention discrimination. ${ }^{18}$ Since dismissal and demotion are the employer's prime weapons, virtually all employer unfair practices meet this "employment relationship" test.

But union unfair practices causing wage loss frequently do not meet the test. The Board has confined back pay awards against unions to situations in which the union, in violation of Section 8 (b) (2), ${ }^{10}$ causes an employer to discriminate against a worker. ${ }^{20}$ Then a union refuses to allow a worker ingress to his place of employment-an act violative of Section $8(b)(1)(A)^{21}$-both the NLRB and the Seventh Circuit have held the Board powerless to award back pay because of the absence of discrimination. 2

14. See Progressive Mine Workers v. NLRB, 187 F.2d 298 (7th Cir. 1951); Cnited Mine Workers of America, 92 N.L.R.B. 916 (1950); United Furniture Workers of America, S4 N.L.R.B. 563 (1949). Also sie Northern Electric Manufacturing Co., \&4 N.L.R.B. 136, 157 (1949) : National Maritime Union of America, 78 X.L.R.B. 971,959 (1948).

15. For the wording of these sections, see notes $4,5,7$ supra.

16. United Furniture Workers of America, S4 N.L.R.B. 563 (1949).

17. Gullett Gin Co. v. NLRB, 179 F.2d 499 (5th Cir. 1950). The Board found that the discharge of employees in violation of $\S S(a)(1)$ amuunted to " $a$ discrimination in hire and tenure of employment." Gullett Gin Co., 83 N.L.R.B. 1, 2 (1949); cf. InterCity Advertising Company of Greensboro, N.C., Inc., S9 N.L.R.B. 1103, 1138 (1950) (company discriminated against D. D. Peeler by firing him in violation of $\$ \$(a)(1)$ ).

1S. See note 3 supra.

19. See note 7 supra.

20. Because of such restrictions of back pay to $\$ 8(b)(2)$ violations, NLRB counsel, attempting to recover back pay from unions, have sometimes been forced to allege $\$ 8(b)$ (2) violations in situations in which the language of the section appears inappropriate. See Local Union No. 62S1, United Mine Workers of America, 30 LAd. REL. Rer. MAnt: 1292, 100 N.L.R.B. No. 64 (1952) (\$\$\&(b) (1) (A) and $\$(b)(2)$ violatiuns alleged; Board found only a $\$ S(b)(1)(A)$ violation since there was no colorable cneuuragement or discouragement of union membership; hence, no back pay award).

21. See note $S$ supra.

22. See cases cited note 14 supra.

No direct attempts have been made to claim back pay for possible losses incurred as a result of jurisdictional strikes in violation of $\$ \$(b)(4)(D)$. Such losses could be recovered in a damage action under $\$ 303$ of the Act. See note 13 supro. But beeause of the inadequacy of this remedy, see Note, 61 YALE L.J. 745 (1952), it is possible that efforts will be made to secure back pay under $\$ S(b)(t)(D)$. 
The Board's position was first defined ${ }^{23}$ in United Furniture Workers of America. ${ }^{24}$ The union, to enforce a strike, kept workers from the plant against their will by threats and physical violence. Although this violated Section 8 (b) (1) (A), and had clearly deprived workers of wages, the Board refused to award back pay. ${ }^{25}$ Since there had been no "severance of or interference with the tenure or terms of the employment relationship," there had been no discrimination. ${ }^{20}$ The union's conduct had merely interfered with the "right of ingress to the plant" in violation of Section 8(b)(1)(A). Uncler stuch circumstances, a back pay award would not represent "compensation" but rather "damages"-a remedy which the Board lacked power to grant.

23. The Board first referred to the proviso in a dictum in General Electric X-Ray Corp., 76 N.L.R.B. 64, 67 (1948), where it said:

"The proviso is intended to provide for cases arising under Section $8(b)$ of the amended Act ... where a labor organization is 'named in the complaint' and is found to have committed an unfair labor practice in violation of Section $8(\mathrm{~b})$."

But in dictum in National Maritime Union of America, 78 N.L.R.B. 971, 989 (1948), enforcenent granted, 175 F.2d 686 (2d Cir. 1949), cert. denied, 338 U.S. 954 (1950), the Board viewed the proviso as having changed $\S 10$ (c) insofar as it required that the union contribute back pay where it is responsible for discrimination against an employee. In the trial examiner's report in Northern Electric Manufacturing Ca., 84 N.L.R.B. 136, 157 (1949), this was apparently interpreted as meaning that only in cases of discriminatory firing could back pay be awarded.

24. 84 N.L.R.B. 563 (1949).

25. The trial examiner declined to award back pay for policy reasons. He held that in situations such as this, workers could "receive . . protection . . . through the police." Id. at 589. The trial examiner, however, overlooked the fact that the police may in fact be unwilling or unable to furnish protection. In United Mine Workers of America, 92 N.L.R.B. 916 (1950), not only were the local police incapable of preventing the use of force and violence by union organizers, but they appeared to be in sympathy with the activities of the organizers. The trial examiner noted that "[t]he invasion and seizure of the mines by the large group of UMW men, numbering 2,000 or more, [was] of such size and fixed determination that the sheriff and State patrol officers professed their inability to halt or stop them in their announced purpose to invade and shut down the mines. . . . [T] he officers of the law advised that there was 'no other choice' if 'violence and property damage' were to be avoided. ..." Id. at 948. Yet "violence and property damage" followed and workers lost work. See also National Union of Marine Cooks \& Stewards, 87 N.L.R.B. 54, 71 (1949).

26. United Furniture Workers of America, 84 N.L.R.B. 563, 565-6 (1949). The Board further stated that cases involving interference with the employment relationship were the ordinary ones in which back pay was awarded and to which $\$ 10(\mathrm{c})$ of the Act had been held for many years to refer. No cases were cited. If the Board was alluting to cases decided before the Taft-Hartley Act, its statement is misleading. At that time, the relief available through $\S 10(\mathrm{c})$ was only against employer unfair labor practices; now both employer and union unfair labor practices are proscribed.

27. The Board supports its distinction between "compensation" and "damages" by citing National Maritime Union of America, 78 N.L.R.B. 971 (1948). In that calse all employer sought to recover the damages he suffered as a result of a union strike in viom lation of $\S 8(\mathrm{~b})(2)$. But the Board held that it was without power to assess damages in such a situation and noted that other sections of the Act provided such a remedy. 
From the viewpoint both of statutory interpretation and of practical effects, the Board's position appears unsound. The proviso declares that "where an order directs reinstatement . . . back pay may be required of the ... [party] responsible for the discrimination. . . ." If "discrimination" is properly a limitation, "reinstatement" is equally so: yet the Board has refused to malie back pay dependent upon reinstatement orders. ${ }^{29}$ Moreover, as a practical matter, once "discrimination" is defined to mean "interference with the employment relationship," as opposed to physical interference with an employee's going to work, employers unfairly causing wage losses will almost always "discriminate." Unions causing similar losses, on the other hand, frequently will not "discriminate." But the end result is precisely the same in each case: employees are injured to the extent of their wage losses. And the unfair practice causing injury may, if anything, be more undesirable in the case of Section 8 (b) (1) (A) union coercion than where an employer orders dismissal: in the former case, pay loss is frequently accompanied by physical abuse. 0

Despite the weakness of United Furniture, both the Board and the Seventh Circuit have strongly reaffirmed its holding. In Unitid Mine Workers, ${ }^{31}$ the Board, over strong dissent, ${ }^{32}$ relied on United Furniture and refused to award back pay for a Section S(b)(1)(A) violation alone. And the Seventh

However, in cases such as United Furniture, the Board was faced with the request of embloyees for their wage losses. While the Board could just as logically have called the payment of such losses "compensation," it chose instead to deny relief by attaching the label of damages.

28. 61 STAT. 147 (1947), 29 U.S.C. \$160(c) (Supp. 1952).

29. Ambassador Venetian Blind Workers' Union, Local No. 2565, 92 N.L.R.B. 902 (1950) ; National Union of Marine Cooks \& Stewards, C.I.O., 92 N.L.R.B. 877 (1950); Pen \& Pencil Workers Union, Local 19593, 91 N.L.R.B. $8 \$ 3$ (1950).

30. See cases cited note $S$ stpra. See also note 25 supra.

31. 92 N.L.R.B. 916 (1950).

32. In dissenting, Member Reynolds reversed the position he tools in Utsited Fumilure Workers. Reynolds' change of mind was based on a "comprehensive study" of: the Supreme Court decisions interpreting $\$ 10(c)$ prior to its amendment, the language of $\$ 10(c)$, and the legislative history of the amendment to $\$ 10(\mathrm{c})$.

In referring to Phelps Dodge, sipra note 12, Reynolds stated that the Court's language ". . . beyond peradventure of a doubt, affirmed the power of the Board to talie whatever affirmative action it believes will effectuate the policies of the Act, without imposing thereon any limitation by reason of the illustrative example referring to reinstatement. As the Section 10(c) proviso is likewise merely illustrative of the Board's power, it follows that the proviso does not delimit the Board's remedial power." Unites Mine Workers of America, 92 N.L.R.B. 916, 922 (1950).

Reynolds summed up his position in the following words:

"In this case, the Respondents, through the exercise of illegal coercive tacties which rendered civil authority helpless, caused a temporary hiatus in the tenure of employment of the employees of the Employer thereby causing them a loss in p3y.... [T] he Respondents should be required to make whole the employees for the loss of pay suffered. Only in this way can the unfair labor practice committed by the Respondents be efiectively remedied." Id. at 925-6. 
Circuit, in Progressive Mine Workers $v . N L R B, 33$ expressly approved United Furniture and denied back pay to two workers forced to leave their jobs by threatened violence.

A recent opinion of the Eighth Circuit, NLRB v. J. I. Case Co. ${ }^{34}$ however, suggests a broadened view of the Board's back pay power under the TaftHartley proviso. Several workers, to protest the firing of another worker, had unsuccessfully attempted to incite a walkout and had been either fired or laid off. The workers alleged, and the Board held, ${ }^{35}$ that the employer had violated Section $8(a)$ (1) by interfering with their right to engage in concerted activities, and had violated Section $8(a)(3)$ by discriminating against them to discourage union membership. But the Court of Appeals, holding that the employer's action was not intended to discourage union membership, rejected the findings as to Section 8(a)(3). ${ }^{30}$ It upheld only the Section 8(a) (1) violation and awarded back pay for that unfair practice alone. ${ }^{37}$ Earlier cases awarding back pay in such situations had involved findings of "discrimination."38 The Eighth Circuit, however, apparently assumed that "discrimination" was confined to Section 8(a)(3) violations. And without referring to United Furniture or Progressive, the court itself interpreted Section 10(c): "[U]se of the term 'discrimination' in the proviso" was "casual description only, and not an injected limitation...." ${ }^{30}$ The proviso .did not limit the Board's power to order back pay but rather expressly extended it to "labor organizations, as well as employers, when they engage in unfair practices under the Act." 40

Although J. I. Case involved only an employer unfair labor practice, application of its reasoning would necessitate removal of the limitations imposed by the Board upon its own power to charge unions with back pay. The language of the proviso applies equally to both "the employer or labor organization ... responsible for the discrimination."41 If discrimination is not a proper test for establishing employer liability, neither should it be used to restrict union liability. ${ }^{42}$

Adoption of the Eighth Circuit's interpretation of the proviso thus reaches a desirable result. But it fails adequately to explain Congress' reason for in-

33. 187 F.2d 298 (7th Cir. 1951).

34. 198 F.2d 919 (8th Cir. 1952).

The court relied on J. I. Case to reach a similar conclusion in Modern Motors v. NLRB, 198 F.2d 925 (8th Cir. 1952) (employees discharged for protesting non-payment of Christmas bonus). Both cases were decided on the same day.

35. J. I. Case Co., 95 N.L.R.B. 47 (1951).

36. NLRB v. J. I. Case Co., 198 F.2d 919, 923-4 (8th Cir. 1952).

37. Id. at 922 .

38. See cases cited note 17 supra.

39. NLRB v. J. I. Case Co., 198 F.2d 919, 924 (8th Cir. 1952).

40. Ibid.

41. 61 Stat. 147 (1947), 29 U.S.C. $\$ 160$ (c) (Supp. 1952).

42. The statement of policy set forth in Section 1 of the Taft-Hartley Act also indicates a congressional intent to treat employers and unions alike. 61 STAT. 136 (1947), 29 U.S.C. \& 141 (Supp. 1952). 
serting this confusing clause. Since the Board's power prior to Taft-Hartley was broad enough to cover any unfair labor practice, insertion of the proviso would, on its face, seem unnecessary if its purpose were merely to extend the Act to "labor organizations, as well as employers."13

Commentators, attempting to explain the reason for the Taft-Hartley amendment to Section 10 (c). have advanced an alternative interpretation. ${ }^{\text {is }}$ This would read the NLRB's broad power to award lost wages as undisturbed by the proviso. The only effect of the statement that "back pay may be required of the employer or ${ }^{45}$ labor organization ... responsible for the discrimination" would be to prohibit joint awards against both unions and employers where a union violates Section $S(b)(2)$ by inducing an employer to discriminate. But there is little justification for this position. and the Boart has rejected it. ${ }^{46}$ Joint awards may in fact be desirable since both parties may be at fault. ${ }^{47}$ And it is unlikely that Congress would rely entirely upon the word "or" to bar joint awards; it could easily have prohibited them specifically.

Examination of the legislative history of the Taft-Hartley . 1ct, however, suggests another interpretation of the proviso which would permit the desirable result achieved by the Eighth Circuit and, at the same time, clarify the ambiguous statutory language. Although relevant evidence of congressional intent is far from conclusive, it seems to suggest that Congress intended to make back pay available for all unfair practices depriving workers of wages. In adding the present proviso, ${ }^{48}$ the Conference Committee declared simply

43. NLRB v. J. I. Case Co., 198 F.2d 919, 924 (Sth Cir. 1952).

44. See Petro, Union Liability For Back Pay Under the NLRA, 2 LAB. LJ. 83 (1951); Perkins, supra note 13, at 401.

45. Emphasis added.

46. Union Starch \& Refining Co. v. NLRB, 186 F.2d 1008, 1014 (7th Cir.), ccrt. denied, 342 U.S. 815 (1951); American Pipe \& Steel Corp., 93 N.I.R.B. 54 (1951); Acme Mattress Co., 91 N.L.R.B. 1010 (1950); H. Miilton Newman, 85 N.L.R.B. 725 (1949).

47. For a discussion of the policies favoring such an award, see Acme Alattreas $C_{0,}$ 91 N.L.R.B. 1010 (1950).

48. A provision somewhat different from that finally enacted was passed by the House. This empowered the Board "... to take such affirmative action requested in the complaint (which in the case of unfair labor practices under section $8(a)$ may include reinstatement of employees with or without back pay, and in the case of unfair labor practices under section $S(b)$ or $S(c)$ may include deprivation of rights under this Act for a period not exceeding one year) as will effectuate the policies of this Act." H.R. 3020 , 80th Cong., 1st Sess. $\$ 10$ (c) (1947).

The accompanying House Report stated that this section "in language like that which is applicable to employers who violate section $8(a)$, authorizes the Board to order unions and their adherents who violate section $S(b)$ to cease and desist from their unfair practices and to take such affirmative action as will effectuate the policies of the act. The Board is authorized to deprive them of rights under the act for a period of not more than 1 year. Under this clause the Board may also require a union to reimburst tu an cmplosk whom it causes to lose pay the amount that he loses." H.R. ReP. No. 245, E0th Cong, 1st Sess. 42 (1947). 
that the amendment was necessary to give the Board power to require back pay of unions which induce an employer to discriminate. ${ }^{40}$ But there is nothing in this statement to warrant the NLRB's conclusion that the proviso describes the only situation in which back pay may be charged to a union." Rather, it may have indicated a congressional fear that existing statutory language, if left unaltered, would have required that a back pay order and an accompanying reinstatement order both be directed against the same party. Prior to the Taft-Hartley Act, if a case involved both back pay and reinstatement orders, the two orders were necessarily directed against the same party-the employer. ${ }^{51}$ But Taft-Hartley made it unfair for a union to cause an employer to discriminate. ${ }^{\overline{0} 2}$ In such situations, therefore, the Board might wish to direct an employer to reinstate an injured worker while, at the same time, ordering the union to restore lost wages.53 So Congress may simply have added the proviso to permit the NLRB to divorce back pay orders from reinstatement orders. In fact, the proviso was described in congressional debate as broadly "authorizing the Board to charge unions with back pay, in the event the union is guilty of an unfair labor practice. . . ."54

Clarification of the meaning of Section 10(c) should be included among the proper objectives of the impending legislative revision of the Taft-Hartley Act. And revision should be directed toward asserting the Board's power to award back pay for any unfair labor practice. Alternatively, acceptance by the NLRB of the Eighth Circuit's position that discrimination is not essential in back pay cases could lead to a similar result. In any event, the NLRB's present approach to union unfair practices should be discarded in favor of one better equipped both to deter such undesirable activity and to compensate injured workers.

49. "The language of the Senate amendment without which the Board could not require the unions to pay back pay when they induce an employer to discriminate against an employee is included in the conference agreement." H.R. CoNF. REP. No. 510, 80th Cong., 1st Sess. 54 (1947).

50. In fact, there is language in the Conference Report to suggest that the Committee was satisfied with the back pay provisions of the House bill. See note 48 supra. The Conference Committee objected to the limitations the House bill placed on the Board's remedial powers in cases "not involving back pay." H.R. CoNF. REp. No. 510, 80th Cong., 1st Sess. 54 (1947) (emphasis supplied).

51. The wording of $\S 10(\mathrm{c})$ - "reinstatement ... with or without back pay"-makes it clear that reinstatement orders could be issued unaccompanied by back pay orders. And the NLRB and courts have also permitted issuance of back pay orders unaccompanied by reinstatement orders. See, e.g., Phelps Dodge Corp. v. NLRB, 313 U.S. 177 (1941); NLRB v. National Garment Co., 166 F.2d 233 (8th Cir. 1948); Na-Mac Products Corp., 70 N.L.R.B. 298 (1946).

52. 61 SrAT. 141 (1947), 29 U.S.C. § 158 (b) (2) (Supp. 1952).

53. In fact, however, the Board has thus far held that the policies of the Act will best be effectuated by ordering joint back pay awards. A departure from this approach was urged by Chairman Herzog and Member Reynolds in a dissenting opinion in Acme Mattress Co., 91 N.L.R.B. 1010, 1021 (1950).

54. Remarks of Senator Hatch in support of the amendments to $\S 10(\mathrm{c}) .93$ Covc. REC. 5005 (1947). 